\title{
Lausetyyppien sekoittuminen edistyneessä oppijansuomessa - näkökulmana eksistentiaalilause
}

\author{
ILMARI IVASKA \\ Turun yliopisto
}

Tiivistelmä. Kielenoppijoiden syntaksia tarkasteltaessa tukeudutaan usein lausetyyppeihin. Tarkastelutavan etuna ovat sen kattavuus, pedagoginen sovellettavuus ja kielen luonnollisten omaksumismallien huomioonottaminen. Todellisen kielen tekstilauseet eivät ole millään lailla selvärajaisia kategorioita, vaan niissä sekoittuu usein piirteitä useista eri lausetyypeistä. Oppijankielessä ilmenevä epäidiomaattisuus voidaan kuitenkin monesti nähdä koko rakenteen epäidiomaattisuutena, joka puolestaan juontaa eri lausetyypeille ominaisten elementtien yhdistymisestä yhdessä lauseessa. Tässä artikkelissa tarkastellaan oppijansuomen lausetyyppejä ja lausetyyppien välistä sekoittumista. Tarkastelun lähtökohtana on olemassaoloa kuvaava eksistentiaalilause. Artikkelissa erotellaan kolme lausetyyppien sekoittumisen alalajia: 1) jonkin jäsenen kontekstiin nähden epäidiomaattinen muoto, 2) joidenkin jäsenien kontekstiin nähden epäidiomaattinen järjestys ja 3) jonkin kontekstin vaatiman jäsenen puuttuminen. Ilmiöiden kontekstisidonnaisuudella tarkoitetaan sitä, että kulloinkin kyseessä olevan tapauksen idiomaattisuuteen jossain toisessa esiintymisympäristössä ei oteta kantaa. Oppijansuomen syntaksille on tyypillistä, että näistä alalajeista esiintyy epäidiomaattisissa lauseissa samanaikaisesti useita. Tulokset osoittavat, että syntaksin epäidiomaattisuutta kannattaa useimmiten lähestyä koko rakenteen epäidiomaattisuutena ennemmin kuin yksittäisen muotopiirteen epäidiomaattisuutena. Artikkelissa 
pohditaan myös metodin ja tulosten sovellettavuutta annotoidulla korpuksella tehtävään tutkimukseen.

Avainsanat: oppijankieli; korpustutkimus; syntaksi; syntaktiset lausetyypit; eksistentiaalilause; suomi toisena kielenä

\section{Johdanto}

Kun perehdytään maailman eri kielistä tehtyjä lausetyyppikuvauksiin, huomataan, että niitä on kehitetty usein juuri sellaisista kielistä, joita eiensikieliset puhujat harrastavat (ks. esim. Inaba 1996: 12-13). Niin ikään tarkasteltaessa kielenoppijoiden tuottamaa suomea (S2) syntaksin ja sen idiomaattisuuden kannalta, päädytään monesti lausetyyppilähtöiseen näkemykseen. Lausetyyppilähtöinen lähestyminen syntaksiin ei toki ole itsessään millään lailla ensisijainen tapa toimia S2-alalla. Lähestymistä kuitenkin puolustaa moni seikka. Pedagogiselta kannalta lausetyypit tarjoavat niin kielenoppijalle kuin -opettajallekin kattavan ja muuttujiltaan rajallisen keinon tarkastella syntaksin kaltaista abstraktia ilmiövyyhtiä. (Ks. esim. Norman 1993: 135-136; Siitonen 1993: 118-119.) Samanaikaisesti lausetyyppi-lähtöinen tarkastelu soveltuu hyvin ajatukseen kielen omaksumisesta ympäristön tarjoaman lingvistisen - niin laadullisen kuin määrällisenkin - kokemuksen kautta (engl. Usage-based Models; ks. esim. Kemmer \& Barlow 2000; Tomasello 2003). Lausetyypit ovat kielestä itsestään kumpuavien rakenteiden frekventeimpiä ja luontaisimpia ilmenemiä. (Ks. esim. Elman ym. 1996.) Toisen kielen syntaksia käsittelevän korpustutkimuksen kannalta lausetyypit ovat niin ikään mielekäs tapa lähestyä lauseoppia. Prototyyppinen rakenne tarjoaa lähtökohdan hakuehtojen määrittelemiseen, ja variaatiota voidaan tarkastella hallitusti hakuehtoja yksittäin muokkaamalla (ks. esim. Ivaska 2010b). Tarkastelu vastaa monilta osin konstruktiokieliopin ajatusta skemaattisista rakenteista, jotka voivat sekoittua todellisessa kielenkäytössä keskenään (konstruktiokieliopista ks. esim. Croft 2001; rakenteiden sekoittumisesta suomen lausetyypeissä ks. esim. ISK 2004: 848).

Tarkastelen tässä artikkelissa edistyneiden suomenoppijoiden kirjoituksessa esiintyviä lausetyyppejä. Pyrin osoittamaan, että lausetyyp- 
peihin perustuva lähestyminen soveltuu erinomaisesti oppijansuomen syntaksin erityispiirteiden tutkimiseen ja että oppijansuomen laadullinen ja määrällinen epäidiomaattisuus voidaan usein nähdä nimenomaan eri lausetyyppien keskinäisen sekoittumisen tai lausetyyppien kohdekielestä poikkeavien roolien ilmentyminä. Todellisen kielen neutraaleissa ja kohdekielen kannalta täysin idiomaattisissa tekstilauseissa on usein piirteitä useista eri lausetyypeistä, mikä ei itsessään ole minkäänlainen merkki epäidiomaattisuudesta. Oppijankielen laadullinen epäidiomaattisuus on kuitenkin tämän tutkimuksen tulosten valossa usein osa koko konstruktion epäidiomaattisuutta. Käsittelen eri lausetyyppien välisen rajankäynnin ilmenemistä oppijansuomessa ns. eksistentiaalilauseen kannalta (eksistentiaalilauseesta ja sitä käsittelevästä monipolvisesta keskustelusta yhteenvetoa ks. esim. Tiainen 1997). Ehdotan lausetyyppien sekoittumiselle kolmea eri ilmenemismuotoa. Tutkimus on osa Turun yliopistossa tehtävää tutkimushanketta Edistyneiden suomenoppijoiden korpus (LAS2). Oppijankielen eksistentiaalisia lauseita on käsitelty aiemmin LAS2:n kahdessa aikaisemmassa julkaisussa (Ivaska 2010a; Ivaska 2010b), joiden jatkoksi tämä artikkeli niveltyy.

\section{Teoria}

\subsection{Lausetyyppi, toisen kielen tutkimus ja korpustutkimus}

Tässä artikkelissa nojaudun ajatukseen lauseiden jaottelusta eri tyyppeihin niiden rakenteen perusteella. Lähestymiseni vastaa monilta osin ns. konstruktiokieliopin käsitystä rakenteista skemaattisina kielenyksikköinä ja rakenteiden ja merkityksen välisten vastaavuuksien keskeisyyttä kielen peruselementteinä (ks. esim. Goldberg 1995). En pidä lauseiden syntaktista funktiota sinänsä lausetyypin määrittäjänä, vaan uskon lausetyyppien (kuten rakenteiden ylipäätään) hahmottuvan todellisen kielenkäytön ilmaisujen - kirjoitetussa kielessä ns. tekstilauseiden - frekventeimpinä ja toisistaan erotettavissa olevina konstruktioina (frekvenssiin nojaavasta kielenomaksumisesta ks. esim. Tomasello 2003: 5-6). Toisen kielen omaksumisen tutkimuksessa tätä lähestymistapaa on 
soveltanut esimerkiksi Nick C. Ellis (2002) assosiatiivis-kognitiiviseksi kutsumassaan ajatusmallissa.

Muodon ja merkityksen välisen yhteyden keskeisyyden vuoksi lausetyypin käsitettä ja sen merkitystä toisen kielen tutkimuksen kontekstissa onkin luontevaa havainnoida korpustutkimuksen näkökulmasta valintapreferenssien, myötäesiintymien ja esiintymisehtojen (termeistä ks. Jantunen 2004: 15, 19) ilmentyminä. Vastaavaa lähestymistapaa soveltaa esimerkiksi Mintz kielenomaksumisessa ilmeneviä konstruktioita, niiden osia ja näiden myötäesiintymiä ja esiintymisehtoja sekä pohtiessaan konstruktioiden keskinäisiä suhteita (Mintz 2006).

Edellä kuvattu lausetyyppien ilmeneminen tarkoittaa kielenomaksumisessa yleensä kielestä itsestään nousevien luonnollisten konstruktioiden kehittymistä abstraktimmiksi rakennekokonaisuuksiksi. Nämä morfologisten ja syntaktisten piirteiden osajärjestelmät muodostavat lausetyyppien kaltaisia, eri osajärjestelmien yhteisesiintymien todennäköisyyksien määrittelemiä kokonaisuuksia. (Ks. esim. Tomasello 2003: 98-112.) Oppijankielen järjestelmä on tyypillisesti jatkuvassa muutoksessa. Oppija pyrkii yhtäältä muotojen ja merkityksen väliseen yhdenmukaisuuteen, mutta toisaalta samanaikaisesti oppijan välikieleen omaksumat uudet muodot vaativat merkitys-funktioiden jakamista uusiin, usein entistä spesifimpiin kategorioihin. Tämä prosessi voi synnyttää välikieleen vapaan variaation tilanteita muotojen ja niiden merkitysten välille. (Ellis, R. 1985: 195-196.) Näin ollen äidinkielisen kielenkäyttäjän lausetyyppien käyttöä ohjaa omaksuttujen todennäköisyyksien muokkaama idiomaattisuus (engl. Idiom Principle), kun taas kielenoppijalla tilanne on lähempänä vapaata valintaa (engl. Open-Choice Principle) (Sinclair 1991: 109-110).

\subsection{Lausetyypit S2-tutkimuksessa ja eksistentiaalilause}

Suomen lausetyypeistä puhuttaessa keskustelu on karkeasti ottaen jakautunut kahteen toisistaan osin poikkeavaan näkemykseen, joita kutsun kaksiarvoiseksi ja moniarvoiseksi näkemykseksi. Kaksiarvoisen näkemyksen mukaan suomen syntaksin perustavanlaatuinen piirre on lau- 
seiden jakautuminen normaalilauseisiin ja eksistentiaalilauseisiin (ks. esim. Hakanen 1972), joskin näkemys kahden ääripään välisestä jatkumosta (Huumo \& Perko 1993) lienee nykyisin yleisempi. Moniarvoinen näkemys katsoo suomen lauseopin rakentuvan useista keskenään samanarvoisista lausetyypeistä (ks. esim. Hakulinen \& Karlsson 1979; ISK 2004: 848-849). Rajanveto ei kuitenkaan usein ole todellisuudessa näin jyrkkää, sillä kaksiarvoisesta jaostaan huolimatta esimerkiksi Hakanen erottelee kummassakin kategoriassa alatyyppejä, jotka ovat hyvin samankaltaisia Hakulisen ja Karlssonin ehdottaman moniarvoisen jaon lausetyyppien kanssa. S2-alalla lausetyyppikeskustelulla ja lausetyyppien käytöllä on usein ollut pedagoginen pohjavire (ks. esim. Siitonen 1993; Vähämäki 1993; White 1993: 276-294; Karlsson 2009: 98-102), joskin samat tutkijat ovat usein ottaneet osaa myös suomen lausetyypeistä käytävään yleiseen keskusteluun (ks. esim. Vähämäki 1987).

Ottamatta kantaa koko lausetyyppien kirjoa kattavaan näkemykseen voidaan keskustelusta abstrahoida kolme eksistentiaalilauseelle tyypillistä muotopiirrettä: 1) lauseen subjektiksikin kutsutun e-NP:n mahdollinen partitiivisijaisuus (e-NP:n subjektiudesta ks. esim. Helasvuo 1996: 348-349; Helasvuo \& Huumo 2010: 191-192), 2), e-NP:n ja predikaatin välinen inkongruenssi ja predikaatin intransitiivisuus ja 3) prototyyppisen eksistentiaalilauseen V-e-NP-sanajärjestys. (Ks. esim. Hakanen 1972: 42-43; Vähämäki 1987: 186.) ISK:ssa pidetään näiden tekijöiden lisäksi tyypillisenä sitä, että predikaattina on olla-verbi, että lauseessa on teemapaikkainen paikanilmaus ja että e-NP on aiemmin mainitsematon (ISK 2004: 850). Esimerkki (1) on Hakasen esittämä prototyyppinen eksistentiaalilause, ja esimerkki (2) on tutkimusaineistosta poimittu eksistentiaalinen lause, joka vastaa prototyyppisen lausetyypin muotopiirteitä. Käytän rinnakkain termejä eksistentiaalilause ja eksistentiaalinen lause. Näistä ensimmäinen tarkoittaa prototyyppistä ja abstraktia olemassa olemista kuvaavaa lausetyyppiä (tässä merkityksessä käsitteen Existential Sentence lanseerasi Jespersen 1924: 154-156; suomen kielioppiin termin eksistentiaalilause toi Ikola 1954: 224-226) ja jälkimmäinen todellisen kielenkäyttäjän tuottamaa rakennetta. 
(Ks. tarkemmin Ivaska 2010a: 68.) Koodi tutkimusaineiston esimerkkilauseiden lopussa kertoo kunkin lauseen sijainnin LAS2-korpuksessa.

(1) Huoneessa on pöytä.

(2) Kun kyseessä on toimintatilanne, lauseessa on agentti ja lause on silloin transitiivinen. (las2-7tt01te06)

Ivaska on tarkastellut aiemmin oppijansuomen eksistentiaalisia lauseita niiden e-NP:n sijamerkinnän (2010a) sekä e-NP:n ja verbin välisen sanajärjestyksen (2010b) kannalta, ja Siitonen (2010) on esitellyt fennougristikongressissa 2010 edistyneiden suomenoppijoiden olla-verbillisiä lauserakenteita.

Tarkastelen tässä artikkelissa eksistentiaalilauseen inkongruenssin ilmenemismuotoja oppijansuomessa ja lausetyyppien sekoittumista omana, eri osatekijöistä koostuvana ilmiönään.

\subsection{Lausetyyppien sekoittuminen ja sen alalajit}

Kuten esimerkiksi Häkkinen kirjoittaa, suomen tekstilauseet saattavat edustaa samanaikaisesti useita eri lausetyyppejä (Häkkinen 2005: 61). Samaa näkemystä korostaa myös Inaba todetessaan, että lausetyyppejä toisistaan erottelevat kriteerit ovat ainoastaan samanaikaisesti toimivia konstruktion ja sen eri osien suhteita määrittäviä osajärjestelmiä (Inaba 1996:34). Näiden osajärjestelmien vaikutukset lausetyypin analysoimiseen ovat lisäksi usein monitulkintaisia. Esimerkiksi Vilkuna toteaa, että lauseiden epäprototyyppinen sanajärjestys voi olla joko esiintymisympäristöstä johtuvaa inversiota tai puhdasta suomen sanajärjestyksen joustavuutta vailla suoraa motivoijaa (Vilkuna 1989: 188-189).

Tarkoitan lausetyyppien sekoittumisella sitä, että aineistossa olevassa tekstilauseessa yhdistyy piirteitä useista eri lausetyypeistä. Suomen eksistentiaalilausetta ja oppijansuomen eksistentiaalisia lauseita tarkasteltaessa Inaban mainitsemia osajärjestelmiä ovat e-NP:n sijamerkintä (ks. Ivaska 2010a), verbin ja e-NP:n välinen sanajärjestys (Ivaska 
2010b) ja e-NP:n ja verbin välisen kongruenssin puuttuminen. Nämä osajärjestelmät eivät missään tapauksessa välttämättä aina noudata todellisissa tekstilauseissa eksistentiaalilauseelle prototyyppisiä variantteja idiomaattisessakaan suomessa. Eri osajärjestelmien osittainen autonomisuus ja monitulkintaisuus edistävät osaltaan usean eri lausetyypin piirteiden sekoittumista oppijansuomen tekstilauseissa. Tämä puolestaan voi synnyttää epäidiomaattisia lauserakenteita vielä edistyneilläkin suomenoppijoilla, mistä syystä lausetyyppien sekoittumista on perusteltua tarkastella kunkin yksittäisen osatekijän lisäksi myös omana kategorianaan.

\section{LAS2-korpus ja käytettävä aineisto}

Tämä tutkimus on osa LAS2-tutkimushanketta, ja käytetty aineisto on kokonaisuudessaan osa LAS2-korpuksen tenttivastausaineistoa (korpuksesta tarkemmin ks. esim. Ivaska \& Siitonen 2009; Jantunen \& Piltonen 2009). Tenttivastauksia voidaan pitää autenttisena ja toisen kielen tutkimukseen soveltuvana aineistona siinä mielessä, että vastauksia ei ole kirjoitettu kielentutkimuksen aineistoksi (ks. esim. Granger 2010: 8). Aineistoa on yhdeksältä informantilta (LAS2-1...LAS2-9), ja sitä on yhteensä 2575 virkeriviä (virke tai virkkeen kaltainen tekstuaalinen kokonaisuus), jotka jakautuvat yhteensä 4028 lauseeseen. Osalta informanteista aineistoa on yli vuoden ajalta, mutta tässä artikkelissa keskitytään lausetyyppien sekoittumisen eri tapoihin ja ilmiön yleiseen luonteeseen, ei niinkään pitkittäismuutoksen tarkasteluun. Valmistuessaan LAS-korpus on kattavasti annotoitu niin morfologian kuin syntaksinkin osalta. Tätä artikkelia kirjoitettaessa annotoitu aineisto ei kuitenkaan ole vielä käytettävissä. Analyysissa käytettäviä metodeja voidaan käyttää luontevasti myös korpuksen tulevien hakutyökalujen kanssa, mutta tämän artikkelin analyysi on tehty digitalisoidusta raakatekstistä.

Tutkimuksen yhdeksän informantin ryhmä on hyvin heterogeeninen; ensikielet ovat englanti (LAS2-8), komi (LAS2-6), liettua (LAS2-5, 
LAS2-9), ruotsi (LAS2-3), tšekki (LAS2-2), venäjä (LAS2-1, LAS2-7) ja viro (LAS2-4). Sulkeissa oleva tunnus on informantin tunnistekoodi korpuksessa. Kaikki informantit ovat aineiston keruuhetkellä opiskelleet Turun yliopistossa suomea jossain ei-ensikielisille suomenpuhujille tarkoitetussa koulutusohjelmassa (aineiston luonteesta tarkemmin ks. Ivaska \& Siitonen 2009: 56-57). Heterogeeninen informanttiryhmä mahdollistaa tutkimuksen fokuksen keskittämisen lähtökielten siirtovaikutusten sijaan nimenomaan oppijansuomeen ja sen erityispiirteisiin.

\section{Lausetyyppien sekoittuminen tutkimusaineistossa}

Lausetyyppien sekoittumisen lähtökohtainen kategoriattomuus - tai paremminkin tällaisten tekstilauseiden eri osien kuuluminen keskenään eri kategorioihin - tekee ilmiön yleisestä rakenteeseen perustuvasta tarkastelusta ongelmallista ja osin myös paradoksaalista (vrt. Inaba 1996: 34). Etenkin ilmiön kvantitatiivinen tarkastelu on hankalaa, ja se on luontevaa lähinnä yksittäisten osajärjestelmien osalta. Niinpä tarkastelu kohdistuukin tässä nimenomaan niihin esiintymistapoihin, joiden kautta lausetyyppien sekoittuminen eksistentiaalisissa lauseissa ilmenee. Ei myöskään ole mitään syytä ajatella, että nämä esiintymistavat eivät pätisi muissa lausetyypeissä tai rakenteiden välisissä rajankäynneissä.

Esittelen tässä luvussa lausetyyppien keskinäisen sekoittumisen kolme eri muotoa. Lausetyyppien sekoittumisen tyypilliset ilmenemismuodot ovat seuraavat: 1) kontekstin kannalta epäidiomaattinen lauseenjäsenen muoto, 2) kontekstin kannalta epäidiomaattinen lauseenjäsenten välinen järjestys ja 3) kontekstin kannalta välttämättömän lauseenjäsenen puuttuminen. Tarkoitan näiden ilmiöiden kontekstisidonnaisuudella sitä, että kulloinkin kyseessä olevan ilmiön epäidiomaattisuuteen jossakin toisessa kontekstissa ei oteta kantaa. Nostan analyysin tueksi esimerkkejä tarpeen mukaan. Kuljetan lisäksi läpi tarkastelun esimerkkilausetta (3), jossa ilmenevät kaikki edellä mainitut kolme ilmiötä. Kunkin esimerkin alla on lisäksi esitetty oletettu tavoiterakenne silloin, kun sellaisen esittäminen on mahdollista (tässä 3b). 
(3a) Jos sanat ovat vastineina muissa saman kielikunnassa ja voidaan rekonstruoida kantakieleksi sitä pidetään omaperäisenä. (las2-8tt01te07)

(3b) Jos sanoilla on vastineita muissa saman kielikunnan [kielissä] ---

Tulokset yhdistävät aiempia huomioita edistyneen oppijansuomen e-NP:n muodosta ja verbin ja e-NP:n välisestä sanajärjestyksestä nyt esiteltäviin tuloksiin e-NP:n ja verbin välisestä kongruenssista. Aineiston 2575 virkeriviä sisältävät yhteensä 443 sellaista eksistentiaalista lausetta, jotka mahdollistavat lausetyyppien mahdollisen sekoittumisen tarkastelun.

\subsection{Lauseenjäsenen muoto}

Ensimmäinen lausetyyppien välisen sekoittumisen alaryhmä on lauseet, joiden jokin jäsen on kontekstin kannalta epäidiomaattisessa muodossa. Edistyneiden suomenoppijoiden eksistentiaalisissa lauseissa tyypillisiä tapauksia ovat e-NP:n epäidiomaattinen sijamerkintä (n. 11 \%:ssa eksistentiaalisista lauseista, Ivaska 2010a: 76) ja odotuksenvastainen kongruenssi e-NP:n ja verbin välillä. Aineiston 443 eksistentiaalisesta lauseesta 19:ssä on odotuksenvastaisesti kongruoiva predikaatti, eli kongruenssi ilmenee 4,5\%:ssa aineiston eksistentiaalisista lauseista.

On kuitenkin syytä muistaa, että mahdollinen kongruenssi voi näkyä vain niissä lauseissa, joissa on monikollinen e-NP. Tällaisia lauseita on 45 prosenttia aineiston eksistentiaalisista lauseista, joten odotuksenvastainen kongruenssi voi implisiittisesti olla likimain kaksi kertaa yhtä yleistä kuin edellä mainitut luvut antavat ymmärtää. Esimerkit (4) ja (5) kuvaavat e-NP:n ja verbin odotuksenvastaista kongruenssia.

(4a) lauseopissa ovat saattaneet tapahtua muiden kielten vaikutuksesta monet muutokset, suomenärjestys SVO on eri kuin kantakielelle oletettu SOV, mutta esiintyy myös vain suomalais ugrilaisille kielille tyypilliset ilmiöt: rektiot: \{esimerkki\} löytää jostakin, mennä kalaan/ marjaan yksikössä. (las2-2tt01te04) 
(4b) lauseopissa on saattanut tapahtua muiden kielten vaikutuksesta monia muutoksia ---

(5a) Varhaiskantasuomessa sanojen takavokaaleina alkoivat olla myös muut vokaalit. (las2-5tt01te07)

(5b) Varhaiskantasuomessa sanojen takavokaaleina alkoi olla myös muita vokaaleja.

Esimerkkien (4) ja (5) lauseet ovat kongruenssia lukuun ottamatta selvästi eksistentiaalisia lauseita niin merkitykseltään kuin rakenteeltaankin. Niissä e-NP on kuitenkin nominatiivisijainen, mikä on mahdollista kaikkien lausetyyppien subjekteille. Molemmissa tapauksissa nominatiivisijaisuus on lisäksi epäidiomaattinen valinta e-NP:lle. Voidaankin ajatella, että informantit LAS2-2 ja LAS2-5 ovat hahmottaneet kyseiset lauseet ensikieleltään suomenkielisten intuitiosta poikkeavasti. Esimerkin (4) voi nähdä muistuttavan sanajärjestykseltään epäprototyyppistä mutta kaikin puolin hyväksyttävää ei-eksistentiaalista lausetta. e-NP:n selvä indefiniittisyys yhdessä lauseen semantiikan staattisuuden kanssa kuitenkin edellyttävät eksistentiaalista rakennetta. Lauseet ovat myös keskenään hyvin samankaltaisia, minkä voidaan osaltaan arvella tukevan ajatusta siitä, että lauseet vastaavat informanttien välikielissä keskenään samaa lausetyyppiä. Ne kuvastavat niin ikään laajempaa lausetyyppien sekoittumisen tendenssiä - sitä, että useat epäidiomaatiset seikat lankeavat yhteen ja lisäävät toistensa todennäköisyyttä.

Muodoltaan epäidiomaattisten lauseenjäsenten ryhmään kuuluvat myös tapaukset, joissa lauseen semanttinen e-NP ei saa sille kuuluvaa sijamerkintää (nominatiivi tai partitiivi), vaan esimerkiksi essiivin. Aiemmin esitelty esimerkki (3) kuvastaa tätä ilmiötä.

Esimerkin eksistentiaalisen lauseen essiivisijainen vastineina tuntuu odotuksenmukaiselta e-NP:ltä. Lause on kuitenkin rakenteeltaan monilta osin ei-eksistentiaalinen, minkä mukaisesti syntaktiseksi subjektiksi on jäsentynyt sanat (oletetussa rakenteessa adessiivisijainen adverbiaali sanoilla tai vaihtoehtoisesti allatiivisijainen sanoille). Vaikuttaa siltä, että subjekti tai e-NP on käsitetty lauseelle välttämättömäksi jäseneksi, mutta lause sisältää silti elementtejä useasta eri lausetyypistä. 
Aineistossa on lisäksi 7 sellaista lausetta, joissa on jokin eksistentiaaliselle lauseelle ominainen muotopiirre tai muotopiirteitä mutta joita joko ei voida pitää yksiselitteisesti eksistentiaalisina lauseina tai lauseen tyyppiin on mahdotonta ottaa minkäänlaista lopullista kantaa. Kuudessa tapauksessa lauseessa on subjektiksi/e-NP:ksi jäsentyvä partitiivisijainen NP ja yhdessä tapauksessa subjektin/e-NP:n ja predikaatin väliltä puuttuu lisäksi kongruenssi. Esimerkit (6) ja (7) kuvaavat tapauksia, joissa on subjektiksi/e-NP:ksi jäsentyvä partitiivisijainen jäsen, esimerkeissä (7) ja (8) subjektin/e-NP:n ja predikaatin väliltä puuttuu kongruenssi.

(6a) Erityispiirteitä näillä käsitteillä ovat kuitenkin niin sumeita, että monet tutkijat pitävät esimerkiksi ja tuotenimen yhtenä ja samana käsitteenä. (las2-1tt01te05)

(6b) Näiden käsitteiden erityispiirteet ovat kuitenkin niin sumeita ---

(6c) Näillä käsitteillä on kuitenkin niin sumeita erityispiirteitä ---

(7a) Myöhemmin ymmärrettiin, että joiden sanojen yhtäläisuuksia oli vain satunnainen tarkammin tarvittiin. (las2-8tt01te07)

(7b) --- joidenkin sanojen yhtäläisyydet olivat vain satunnaisia ---

(7c) --- joissakin sanoissa yhtäläisyyksiä oli vain satunnaisesti ---

Esimerkissä (6) on partitiivisijainen sumeita, joka vaikuttaa sanajärjestyksen, sijamerkinnän ja sanan semantiikankin kannalta predikatiivilta. Näin ollen kyseinen tekstilause vaikuttaa olevan niin merkitykseltään kuin rakenteeltaankin lähinnä predikatiivilausetta, jonka subjektilla on odotuksenvastaisesti e-NP:lle ominainen sijamerkintä. Mahdollinen subjektin epäidiomaattisen sijamerkinnän motivoija saattaa olla adverbiaaliksi merkitty näillä käsitteillä, joka hahmottuu semanttisesti ennemmin subjektin määritteeksi. Tämän tulkinnan mukaan lauseen subjekti jäsentyisi muotoon näiden käsitteiden erityispiirteet. Lauseessa on kuitenkin kaikki eksistentiaalisen lauseen elementit - partitiivisijainen e-NP, lokatiivisijainen adverbiaali ja olla-verbi - mikä on omiaan hämärtämään tekstilauseen suhdetta mihinkään yksittäiseen lausetyyppiin.

Esimerkin (7) tapauksessa lauseen alussa oleva joiden sanojen yhtälaisuuksia on luontevaa tulkita subjektiksi ja predikaatin jälkeinen 
satunnainen predikatiiviksi. Saattaa myös olla, että kontekstissa aiemmin esiintynyt virke on osaltaan motivoinut lauseen rakennetta ja lauseenalkuisen lausekkeen partitiivisijaisuutta. Mahdollinen motivoiva lause on kuitenkin niin etäällä, että tämä on epätodennäköistä eikä missään tapauksessa idiomaattista.

(8a) Merkitysparafraasien avulla 1900-luvulla voidaan erottaa siinä, mitkä ovat teettoverbeja, vaikka ei aina voi erottaa koska kuratiivisia verbeja on melko lähellä. (las2-8tt01te05)

(8b) --- kuratiiviset verbit ovat melko lähellä [teettoverbejä] ---

Esimerkissä (8) partitiivisijainen kuratiivisia verbejä ja kongruenssia noudattamaton predikaatti ohjaavat tulkitsemaan lauseen eksistentiaaliseksi. Lauseen semantiikkaa tarkastellessa tämä tuntuu kuitenkin epätodennäköiseltä. Lause voidaankin tulkita intransitiivilauseeksi, jonka adverbiaalilausekkeesta melko lähellä puuttuu jotakin. Lausekkeeseen voisi tulla esimerkiksi teettoverbejä tai jokin näihin viittaava, partitiivisijainen pronomini. Sanan puuttuessa lauseen kaikki elementit viittaavat eksistentiaaliseen lauseeseen, mikä on saattanut motivoida lausekkeen kuratiivisia verbeja partitiivisijaisuuden ja tämä edelleen predikaatin kongruoimattomuuden.

Lauseiden tulkinta on monilla tavoin hyvin tapauskohtaista ja kokonaisuuden kannalta osin jopa perifeeristä. Yksittäistapausten analysointi on kuitenkin välttämätöntä, kun halutaan tarkastella lausetyyppien sekoittumista ilmiönä ja sitä, miten tämä ilmiö näkyy edistyneiden suomenoppijoiden eksistentiaalisten lauseiden suhteessa muihin lausetyyppeihin.

\subsection{Lauseenjäsenten järjestys}

Toinen lausetyyppien välisen sekoittumisen alaryhmä on lauseet, joiden jotkin jäsenet ovat lauseen esiintymiskontekstin kannalta epäidiomaattisessa järjestyksessä. Kuten Hakanen kirjoittaa, pelkkä sanajärjestys voi vaikuttaa sanojen syntaktiseen tulkintaan ja joissakin tilanteissa se on 
ainoa eksistentiaalisen lauseen ja normaalilauseen erottava toisistaan erottava tekijä (Hakanen 1972: 46). Toisaalta esimerkiksi Vilkuna huomauttaa, että verbin ja objektin muodostamat parit ovat semantiikaltaan huomattavasti samankaltaisempia intransitiivisten lauseiden subjektin ja verbin kanssa kuin transitiivisten lauseiden subjektin ja objektin kanssa (Vilkuna 1989: 156). Näiden tekijöiden huomioon ottaminen on ensiarvoisen tärkeää lauseenjäsenten järjestystä tarkasteltaessa.

Eksistentiaalisten ja ei-eksistentiaalisten lauseiden sekoittumista tarkastellessa keskeinen tekijä on e-NP:n ja predikaatin välinen järjestys. Tutkimusaineiston eksistentiaalisista lauseista 42:ssa (10\%:ssa) on epäprototyyppinen e-NP-V -sanajärjestys, mutta näistä vain 12 tapauksessa (3 \%:ssa) ei voida osoittaa kontekstista sellaista tekijää, joka motivoisi epäprototyyppisen sanajärjestyksen (Ivaska 2010b: 43-45). Odotuksenvastaisen kongruenssin ja kontekstissaan epäidiomaattisen sanajärjestyksen yhteisesiintyminen ei ole aineistossa yleistä. Ilmiötä esiintyy kuitenkin informantin LAS2-8 välikielessä, ja tapausten epäidiomaattisuuden on helppo nähdä liittyvän lausetyyppien sekoittumiseen. Esimerkki (9) kuvaa tällaista tapausta.

(9a) Baltilaislainat ovatkin suomessa vaikka arkeologian mukaan suomen kielen esipuhujat eivät asuneet Baltiassa. (las2-8tt01te07)

(9b) Suomessa onkin baltilaislainoja ---

Lause on muotopiirteiltään prototyyppinen intransitiivinen lause, joiden predikaattina on olla-verbi. Semanttisen sisällön tarkastelu kuitenkin osoittaa, että se rinnastuu rakenteellisesta epäprototyyppisyydestään huolimatta ennemmin eksistentiaalilauseeseen. On huomionarvoista, että esimerkissä lankeavat yhteen sekä muodon että järjestyksen epäidiomaattisuus. Tämäkin puoltaa osaltaan ajatusta lausetyyppien sekoittumisen eri osa-alueiden yhteisesiintymistä ja edelleen lausetyyppien sekoittumisen keskeistä roolia tekstilauseen epäidiomaattisuuden selittäjänä.

Esimerkin (3) sanajärjestyksessä ei ole itsessään mitään epäidiomaattista. Predikaattia edeltävä, informantin sijamerkinnän ja sanajärjes- 
tyksen perusteella ei-eksistentiaalisen lauseen subjektiksi koodaama sanat on silti epäprototyyppinen lauseessa, jonka merkitys on selvästi eksistentiaalinen. Yleisesti vaikuttaa siltä, että idiomaattisuudesta riippumatta tekstilauseen epäprototyyppinen sanajärjestys on yksi lausetyyppien hämärtymistä edistävä tekijä vielä edistyneilläkin suomenoppijoilla.

Aineistossa on lisäksi 5 sellaista lausetta, jotka eivät lähtökohtaisesti vaikuta eksistentiaalisilta lauseilta mutta joissa verbi edeltää subjektiksi jäsentyvää NP:a. Esimerkit (10) ja (11) kuvaavat tätä ilmiötä.

(10) Varhaiskantasuomena perinteisia sanarakenteita muutti myös lainasanoja (varsinkin balttilais ja germaniset lainat). (las2-5tt01te03)

(11) Suomalaisugrilaisen kantakielen systeemiä muodosti ns. alkuperäinen tunnusmerkitön preesens ja tunnusmerkillinen yksi menneen ajan tempus (eli preteritti). (las2-5tt01te05)

Esimerkkien (10) ja (11) vaikeatulkintaisuus liittyy ennen kaikkea niiden verbinetisiin partitiivisijaisiin lausekkeisiin sekä predikaattien kongruoimattomuuteen. Kumpikin lause on kuitenkin tulkittavissa transitiiviseksi lauseeksi. Esimerkissä (10) sekä verbinetinen lauseke perinteisia sanarakenteita että verbiä seuraava lainasanoja voidaan tulkita lauseen subjektiksi. Tulkinta riippuu siitä, käsitetäänkö lauseen merkitykseksi 'perinteiset sanarakenteet muuttivat myös lainasanoja' vai 'myös lainasanat muuttivat perinteisiä sanarakenteita'. Valitettavasti edes kontekstin tarkastelu ei selvennä tätä seikkaa, sillä uuden kappaleen aloittavan lauseen lausekkeiden vaikutussuhde toisiinsa voidaan tulkita kummin päin tahansa. Tästä syystä lauseille ei myöskään tarjota oletettua tavoiterakennetta. Seuraavan virkkeen perusteella lainasanoja vaikuttaa todennäköisemmältä subjektilta, mutta lopullista varmuutta tästä ei saada. Muodollisesti tarkastellen lauseesta puuttuu subjektijäsen, ja semanttisesti kumpikin lauseke voi toimia lauseen subjektina tai objektina. Molemmat lausekkeet ovat sitä paitsi monikollisia, mistä syystä subjektin pitäisi joka tapauksessa laukaista verbin kongruenssi.

Käsitän esimerkin (11) subjektiksi lausekkeen ns. alkuperäinen tunnusmerkitön preesens ja tunnusmerkillinen yksi menneen ajan tempus (eli 
preteritti). Se, että tämä lauseke on lauseessa vasta predikaatin jälkeisessä asemassa, on kuitenkin saattanut aiheuttaa sen, että subjekti ei ole laukaissut verbin kongruenssia tai että subjektiksi on käsitetty verbinetinen, partitiivissa oleva lauseke suomalaisugrilaisen kantakielen systeemiä. Lause läheneekin muotopiirteiltään eksistentiaalilausetta, vaikka se on semantiikaltaan selvästi ei-eksistentiaalinen lause.

\subsection{Lauseenjäsenen puuttuminen}

Kolmas lausetyyppien välisen sekoittumisen alaryhmä on lauseet, joista puuttuu jokin kyseessä olevassa kontekstissa välttämätön lauseenjäsen. On syytä todeta, että tämä ilmiö saattaa olla osin tekstilajikohtainen, sillä esimerkiksi aineistona olevat tenttivastaukset ovat luonteeltaan hyvin viimeistelemättömiä tekstejä. Olipa lauseenjäsenen puuttumisen syynä sitten huolimattomuus tai jokin muu syy, lauseesta uupuva mutta sille välttämätön lauseenjäsen edistää niin ikään omalta osaltaan lausetyyppien keskinäistä sekoittumista.

Esimerkin (3) adverbiaalilausekkeesta muissa saman kielikunnassa vaikuttaa puuttuvan sen semanttinen pääsana, jonka voidaan olettaa olevan likimain 'kielissä. Puutteen vuoksi lauseen semanttinen sisältö hämärtyy huomattavasti, mikä puolestaan on omiaan edistämään lausetyyppien välistä sekoittumista.

Puuttuvien lauseenjäsenten ryhmä on luonnollisesti hyvin altis tulkinnan subjektiivisuudelle, sillä mahdollisesti puuttuvien elementtien olettaminen tai olettamatta jättäminen on jo lähtökohtaisesti hyvin tilannekohtaista. Lisäksi puuttuvien elementtien tutkiminen eksplisiittisiin muotopiirteisiin perustuvalla tutkimusmetodilla on vaikeaa. Jonkin lauseenjäsenen mahdollinen puuttuminen on kuitenkin ehdottomasti muistettava ottaa huomioon pohdittaessa oppijankielen syntaksia lausetyyppien kannalta. 


\section{Tulkinta}

Aineiston tarkastelu osoittaa, että edistyneen oppijansuomen syntaktinen epäidiomaattisuus voidaan useimmiten nähdä luontevasti osana koko rakenteen epäidiomaattisuutta, tarkemmin sanottuna lausetyyppien sekoittumista. Tämä ajatus vastaa ainakin osin ns. radikaalin konstruktiokieliopin ajatusta siitä, että konstruktion eri elementit ovat suhteessa nimenomaan konstruktioon itseensä (Croft 2001: 203). Lausetyyppien sekoittumisella tarkoitetaan tässä sitä, että yhdessä luonnollisessa tekstilauseessa on samanaikaisesti piirteitä useasta eri lausetyypistä ja koko rakenteen epäidiomaattisuudella tarkoitetaan näiden erilaisten piirteiden yhteisvaikutusta lauseen epäidiomaattisuudessa. Toisin sanoen rakenteen jäsenten muotoon tai järjestykseen perustuva tulkinta lauseen epäidiomaattisuudesta kohdekielen kannalta perustuu nimenomaan rakenteen epäidiomaattisuuteen.

Edistyneiden suomenoppijoiden eksistentiaalisten lauseiden tarkastelun perusteella lausetyyppien edellä kuvatun kaltaisen sekoittumisen voi jakaa kolmeen tyypilliseen ilmenemismuotoon: 1) lauseenjäsenen kontekstissaan epäidiomaattiseen muotoon, 2) lauseenjäsenten kontekstissaan epäidiomaattisen järjestykseen ja 3) kontekstin vaatiman lauseenjäsenen puuttumiseen. Tutkimusaineiston eksistentiaalisissa lauseissa muodon epäidiomaattisuutta ilmenee ennen kaikkea lauseiden e-NP:iden sijamerkinnässä ja lauseiden odotuksenvastaisesti kongruenssia noudattavissa verbeissä. Sanajärjestyksen osalta lausetyypit voivat sekoittua tutkimusaineistossa e-NP:iden ja verbien välisen sanajärjestyksen odotuksenvastaisen järjestyksen myötä. Puuttumisen osalta aineistosta ei ole osoitettavissa mitään yksittäistä tyypillistä ilmenemismuotoa tai paikkaa, mutta puuttumisen mahdollisuus on syytä ottaa huomioon lausetyyppien välistä sekoittumista tarkasteltaessa.

On syytä huomata, että lausetyyppien sekoittumisen eri muodot lankeavat usein yhteen - esimerkiksi tutkimusaineiston odotuksenvastaisesti kongruoivissa lauseissa on poikkeuksetta myös sijamerkinnältään epäidiomaattinen e-NP. Tämä puoltaa hypoteesia siitä, että oppijankielen syntaktinen epäidiomaattisuus on yhteydessä kokonaisten raken- 
teiden epäidiomaattisuuteen. Tämä taas vahvistaa sitä näkemystä, että lausetyyppien sekoittuminen voi selittää epäidiomaattisuuden laukaisevaa mekanismia, ei vain mahdollista sen kuvaamista. Näin ollen onkin loogista puhua lausetyyppien sekoittumisesta, ei yksittäisten morfosyntaktisten tekijöiden epäidiomaattisista esiintymistä tai normipoikkeamista.

Se, että lauseiden epäidiomaattisuus liittyy nimenomaan eksistentiaalilauseelle ominaisina pidetyissä muotopiirteissä esiintyvään variaatioon, tukee vahvasti eksistentiaalilauseen asemaa suomen lausetyyppinä. Näiden muotopiirteiden synnyttämä lausetyyppien sekoittuminen ja merkityksen hämärtyminen osoittanevat osaltaan myös eksistentiaalilauseen olemassaolon omana kognitiivisena kategorianaan. Kun kategorian yhteydet sille läheisiin kategorioihin poikkeavat välikielessä kohdekielen yhteyksistä, syntyy aineistossa nähtävää, kohdekielen kannalta epäidiomaattista variaatiota.

\section{Annotoidun korpuksen mahdollisuudet konstruktioiden tarkastelussa}

Tämä artikkeli tarjoaa konkreettisia välineitä oppijankielen syntaktisten ominaispiirteiden tarkasteluun. Lausetyyppien keskinäisen sekoittumisen kolme alatyyppiä voivat toimia lähtökohtana oppijankielen syntaksin korpusvetoiseen tutkimukseen. Yhdessä kattavasti annotoidun (muotojen ja funktioiden mukaan merkityn) korpusaineiston kanssa lausetyyppien sekoittuminen on luonteva lähtökohta ns. avainrakenneanalyysille, jossa etsitään korpuksen avulla oppijankieltä ja ensikielisesti käytettyä kieltä toisistaan erottavia syntaktisia tendenssejä (avainrakenneanalyysista ks. Ivaska \& Siitonen, tulossa).

Tässä esitellyn kvalitatiivisen epäidiomaattisuuden lisäksi ei ole mitään syytä ajatella, etteivät lausetyyppien sekoittumisen eri alalajit voisi vaikuttaa osaltaan myös oppijankielen kvantitatiiviseen epäidiomaattisuuteen - vaikkapa jonkin lausetyypin epätyypillisen, joskin ehkä kvalitatiivisesti idiomaattisen muotovariantin yliyleistymiseen oppijan- 
kielessä. Lausetyypit antavat avainrakenneanalyysille kattavan vertailupinnan ja muodollisen lähtökohdan, jonka pohjalta hakuehtoja voidaan muokata. Variaation tavoittamiseksi voidaan edelleen laventaa yhtä hakuehtoa kerrallaan ja näin tavoittaa tässä artikkelissa kuvatun kaltaisia lausetyypin sekoittumisen eri muotoja.

\section{Lähteet}

Croft, William 2001. Radical Construction Grammar: Syntactic Theory in Typological Perspective. Oxford: Oxford University Press.

Ellis, Nick C. 2002. Frequency effects in language processing: A review with implications for theories of implicit and explicit language acquisition. Studies in Second Language Acquisition 24 (2), 143-188. doi:10.1017/ $\underline{\text { S0272263102002024 }}$

Ellis, Rod 1985. Understanding Second Language Acquisition. Oxford: Oxford University Press.

Elman, Jeffrey L., Elizabeth A. Bates, Mark H. Johnson, Annette Karmiloff-Smith, Domenico Parisi, Kim Plunkett 1996. Rethinking Innateness: A Connectionist Perspective on Development. Cambridge, MA: MIT Press.

Goldberg, Adele 1995. Constructions: A Construction Grammar Approach to Argument Structure. Chicago: The University of Chicago Press.

Granger, Sylviane 2002. A Bird's-eye view of learner corpus research. - Sylviane Granger, Joseph Hung, Stephanie Petch-Tyson (Eds.). Computer Learner Corpora, Second Language Acquisition and Foreign Language Teaching. Amsterdam: Benjamins, 3-33.

Hakanen, Auli 1972. Normaalilause ja eksistentiaalilause. - Sananjalka 14, 36-76. Hakulinen, Auli, Fred Karlsson 1979. Nykysuomen lauseoppia. Suomalaisen Kirjallisuuden Seuran toimituksia 350. Helsinki: Suomalaisen Kirjallisuuden Seura.

Helasvuo, Marja-Liisa 1996. Ollako vai eikö olla - eksistentiaalilauseen subjektin kohtalonkysymys. - Virittäjä 100, 340-356.

Helasvuo, Marja-Liisa, Tuomas Huumo 2010. Mikä subjekti on? - Virittäjä 114, 165-194.

Huumo, Tuomas, Jari Perko 1993. Eksistentiaalilause lokaalisuuden ilmaisijana. Virittäjä 97, 380-399.

Häkkinen, Kaisa 2005. Punainen jättiläinen on syntynyt. - Tieteessä tapahtuu 5. Helsinki: Tieteellisten seurain valtuuskunta, 56-62. 
Ikola, Osmo 1954. Suomen lauseopin ongelmia I-III. - Virittäjä 58, 209-245.

Inaba, Nobufumi 1996. Suomen kielen lausetyyppikuvaukseen liittyviä ongelmia: suomalainen 'oleminen' ja suomalainen 'omistaminen'. Julkaisematon pro gradu tutkielma. Turun yliopisto.

ISK 2004 = Hakulinen, Auli, MariaVilkuna, Riitta Korhonen, Vesa Koivisto, Tarja Riitta Heinonen, Irja Alho 2004. Iso suomen kielioppi. Suomalaisen Kirjallisuuden Seuran toimituksia 950. Helsinki: Suomalaisen Kirjallisuuden Seura.

Ivaska, Ilmari 2010a. Eksistentiaalilauseen subjektijäsen edistyneiden suomenoppijoiden kirjoituksessa. - Sananjalka 52, 67-88.

Ivaska, Ilmari 2010b. Mitä syntaktisesti koodattu korpus voi kertoa sanajärjestyksestä? Predikaatti ja subjekti edistyneiden suomenoppijoiden eksistentiaalisissa lauseissa. - Pille Eslon, Katre Õim (Toim.). Korpusuuring ja meetodid. Tallinna Ülikooli eesti keele ja kultuuri instituudi toimetised 12. Tallinn: Tallinna Ülikool, 37-58.

Ivaska, Ilmari, Kirsti Siitonen 2009. Syntaktisesti koodattu oppijankielen korpus: mahdollisuuksia ja ongelmia. - Pille Eslon, Katre Õim (Toim.). Korpusuuringute metodoloogia ja märgendamise probleemid. Tallinna Ülikooli eesti keele ja kultuuri instituudi toimetised 11. Tallinn: Tallinna Ülikool, $54-71$.

Ivaska, Ilmari, Kirsti Siitonen, tulossa. Avainrakenneanalyysi: tapa tutkia oppijankielen lauserakennetta korpusvetoisesti. - AFinLA-e: Soveltavan kielitieteen tutkimuksia 3.

Jantunen, Jarmo H. 2004. Synonymia ja käännössuomi: korpusnäkökulma samamerkityksisyyden kontekstuaalisuuteen ja käännöskielen leksikaalisiin erityispiirteisiin. Joensuun yliopiston humanistisia julkaisuja 35. Joensuu: Joensuun yliopisto.

Jantunen, Jarmo H., Saana Piltonen 2009. Oppijansuomen ja viron sähköiset tutkimusaineistot. - Virittäjä 113, 449-458.

Jespersen, Otto 1924. Philosophy of Grammar. London: George Allen \& Unwin Ltd.

Karlsson, Fred 2009. Suomen peruskielioppi. 4., laajennettu ja uudistettu painos. Suomalaisen Kirjallisuuden Seuran toimituksia 378. Helsinki: Suomalaisen Kirjallisuuden Seura.

Kemmer, Suzanne, Michael Barlow 2000. Introduction: A usage-based conception of language. - Michael Barlow, Suzanne Kemmer (Eds.). Usage-based Models of Language. Stanford: CSLI, vii-xxvii. 
LAS2 = Edistyneiden suomenoppijoiden korpus. Suomen kielen oppiaine, kieli- ja käännöstieteiden laitos, Turun yliopisto.

Mintz, Toben H. 2006. Frequent frames: Simple co-occurrence constructions and their links to linguistic structure. - Eve V. Clark, Barbara F. Kelly (Eds.). Constructions in Acquisition. CSLI Lecture notes 174. Stanford: CSLI Publications.

Norman, Marjatta 1993. Eksistentiaalilauseiden opetuksesta norjalaisten tenttivastausten valossa. - Jyrki Kalliokoski, Kirsti Siitonen (Toim.). Suomeksi maailmalla. Kirjoituksia Suomen kielen ja kulttuurin opettamisesta. Castrenianumin toimitteita 44. Helsinki: Helsingin yliopiston suomen kielen laitos, Helsingin yliopiston suomalais-ugrilainen laitos ja Suomalais-Ugrilainen Seura, 132-141.

Siitonen, Kirsti 1993. Peruslausetyypeistä johdettuja subjektittomia lauseita. - Jyrki Kalliokoski, Kirsti Siitonen (Toim.). Suomeksi maailmalla. Kirjoituksia Suomen kielen ja kulttuurin opettamisesta. Castrenianumin toimitteita 44 . Helsinki: Helsingin yliopiston suomen kielen laitos, Helsingin yliopiston suomalais-ugrilainen laitos ja Suomalais-Ugrilainen Seura, 118-131.

Siitonen, Kirsti 2010. Mitä pitkittäistutkimus paljastaa edistyneiden oppijoiden kielitaidosta. - Esitelmä fenno-ugristikongressissa 10.8.2010. Piliscsaba, Unkari.

Sinclair, John 1991. Corpus, Concordance, Collocation. Oxford: Oxford University Press.

Tiainen, Outi 1997. Suomen eksistentiaalilause - päättymätön tarina. - Virittäjä 101, 563-571.

Tomasello, Michael 2003. Constructing a Language: A Usage-Based Theory of Language Acquisition. Harward: Harward University Press.

White, Leila 1993. Suomen kielioppia ulkomaalaisille. Helsinki: Finn Lectura.

Vilkuna, Maria 1989. Free Word Order in Finnish. Its Syntax and Dinscourse Functions. Helsinki: Suomalaisen Kirjallisuuden Seura.

Vähämäki, Börje 1987. On defining basic sentences in Finnish. - Mauno Koski, Eeva Lähdemäki, Kaisa Häkkinen (Red.). Fennistica festiva in honorem Göran Karlsson septuagenarii. Turku: Åbo Akademis förlag, 174-188.

Vähämäki, Börje 1993. Suomen kielen peruslauseet opetuksen apuna. - Jyrki Kalliokoski, Kirsti Siitonen (Toim.). Suomeksi maailmalla. Kirjoituksia Suomen kielen ja kulttuurin opettamisesta. Castrenianumin toimitteita 44 . Helsinki: Helsingin yliopiston suomalais-ugrilainen laitos, Helsingin yliopiston suomen kielen laitos ja Suomalais-Ugrilainen Seura, 112-117. 


\title{
Clause type confusion in advanced learner Finnish: Existential sentence as our perspective
}

\author{
ILMARI IVASKA \\ University of Turku
}

Clause type -based approach is a common framework in the studies of the syntax of learner language. The advantages of this approach include its comprehensibility, pedagogical applicability and its adaptability in terms of the natural acquisition theories of language, such as different usaga-based models. This paper discusses the clause types of learner Finnish and the phenomenon of mixing up features of several clause types in one actual sentence. The phenomenon of mixing up the features of different clause types is typical in native-speakers' Finnish but is also a source of unidiomatic structures of learner Finnish. The existential sentence of Finnish serves as basis for this observation. Based on our observations, we propose three different subtypes of this mixing-up: 1) formal unidiomacy of a given constituent in the given context, 2) unidiomatic order of two given constituents in the given context and 3) the lack of a constituent mandatory in the given context. It is typical for the syntax of learner Finnish that several of these subtypes occur simultaneously. The results show that the syntactical unidiomacy of learner Finnish should be seen as unidiomacy of the whole structure rather than that of its single constituents. The paper also discusses the applicability of the method and of the results. It suggests they could serve the purposes of corpus-driven learner language studies.

Keywords: learner language; corpus research; syntax; syntactical clause types; existential sentence; Finnish as a second language

\section{IImari Ivaska}

suomen kieli, kieli- ja käännöstieteiden laitos

Fl-20014 Turun yliopisto, Finland

itivas@utu.fi 